\title{
PENGARUH KUALITAS PRODUK, PERSEPSI HARGA, DAN CITRA MEREK TERHADAP KEPUASAN DAN LOYALITAS PELANGGAN BETON SIAP PAKAI HOLCIM DI JAKARTA
}

\author{
Sita Budiastari \\ Magister Manajemen Universitas Negeri Jakarta \\ e-mail:sitarumkana@yahoo.co.id
}

\begin{abstract}
ABSTRAK
Tujuan penelitian ini adalah untuk mengetahui gambaran atas pengaruh kualitas produk, persepsi harga dan citra merek terhadap kepuasan dan loyalitas pelanggan beton siap pakai di Jakarta. Penelitian ini adalah penelitian kuantitatif dengan metode deskriptif dan kausal yang di lakukan di Holcim Beton pada tahun 2013 dengan sampel sebanyak 100 pelanggan di Jakarta dan sekitarnya pada segmen Industrial dan komersial proyek. Pengumpulan data responden dengan kuesioner dan dianalis dengan menggunakan analisa jalur (path analysis) dengan bantuan program SPSS versi 20.0. terhadap kepuasan pelanggan (2) Persepsi Harga berpengaruh positif dan signifikan tehadap kepuasan pelanggan, (3) Citra Merek tidan memiliki pengaruh terhadap Hasil penelitian disimpulkan bahwa (1) Kualitas Produk tidak berpengaruh kepuasan pelanggan, (4) semua variabel bebas, kualitas produk, Persepsi harga dan Citra Merek berpengaruhi positif dan signifikan terhadap variabel terikat Kepuasan Pelanggan, dengan nilai determinasi sebesar 50 $\%$, sedangkan 50\% lainnya di pengaruhi oleh variabel lainnya (5) Kualitas Produk berpengaruh dan signifikan terhadap Loyalitas Pelanggan melalui kepuasan pelanggan, (6) Persepsi Harga tidak berpengaruh terhadap loyalitas melalui kepuasan pelanggan, (7) Citra Merek berpengaruh dan siginikan terhadap loyalitas melalui kepuasan pelanggan, (8) Semua varibel bebas kualitas produk, persepsi harga dan citra merek secara bersama-sama berpengaruh dan signifikan terhadap loyalitas melalui kepuasan pelanggan, dengan nilai determinasi sebesar $77.4 \%$ dan $22.6 \%$ lainnya di pengaruhi oleh faktor lainnya.
\end{abstract}

Hasil temuan mengarahkan untuk merekomendasikan agar Holcim meningkatkan kualitas produk, persepsi harga dan citra merek untuk meningkatkan loyalitas melalui kepuasan pelanggan. Hal ini juga merekomendasikan kepada Holcim untuk meneningkatakan layanan dan informasi kepada pelanggan guna meningkatkan kepuasan dan loyalitas pelanggannya.

Kata kunci: kualitas produk, persepsi harga,citra merek, kepuasan, loyalitas pelanggan, beton siap pakai Holcim di Jakarta. 


\section{PENDAHULUAN}

Saat ini kondisi kebutuhan pada sektor konstruksi di Indonesia memiliki intensitas yang sangat tinggi, salah satunya adalah industri manufaktur semen dan beton. Pertumbuhan konsumsi semen dan beton di Indonesia sejak tahun 2011, meningkat cukup signifikan di bandingkan dengan tahun 2010, maupun tahun-tahun sebelumnya ${ }^{1}$.

PT. Holcim, produsen semen dan bahan material bangunan asal Switzerland yang sudah berdiri sejak 100 tahun lalu, pada tahun 2001 mengakuisisi perusahan semen PT. Semen Cibinong dan semua anak perusahaannya yaitu PT. Semen Nusantara, menjadi PT. Holcim Indonesia. Saat ini Holcim Beton adalah unit bisnis bergerak diindustri beton siap pakai (readymix) dan quarry batu pecah (aggregate).

Beton siap pakai atau readymix concrete adalah campuran antara semen dan aggregate yang di buat di Batchingplant dan di distribusikan ke lokasi tempat pengecoran dengan truk pengaduk, hal ini menjadi satu faktor bagi pembeli dimana harus memperhitungkan faktor waktu sebelum memutuskan menggunakannya. Hampir semua konstruksi bangunan memerlukan beton, dan untuk membuat pekerjaan menjadi effisien, penggunaan beton siap pakai atau ready mix menjadi satu hal yang penting, mengingat biaya konstruksi terbesar terdiri dari besi, semen dan beton.

Di Indonesia dengan adanya Masterplan Percepatan dan Perluasan Pembangunan Ekonomi Indonesia (MP3El) yang akan lebih mendorong pembangunan infrastruktur sehingga kebutuhan semen untuk proyek-proyek infrastruktur akan merubah pangsa pasar semen curah menjadi lebih membesar, sampai saat ini konsumsi semen Indonesia masih pada peringkat rendah dibandingkan negara-negara lain di dunia.

Holcim menyadari akan adanya permintaan yang bertambah, peluang yang besar serta kondisi pesaing yang mulai ekspansi secara agresif, sehingga perlu memperbaiki kinerja yang lebih baik guna memenuhi kepuasan para pelanggannya. Walaupun untuk saat ini belum terlalu menjadi ancamnya bagi Holcim, namun bilamana di telaah dari data table 1.1 mengenai Survey Kepuasan Pelanggan atau Customer Satisfaction Index Holcim pada tahun 2011 mengalami penurunan dibandingkan tahun 2010:

\footnotetext{
${ }^{1}$ Warta Semen Beton Indonesia Vol 10, No 1, tahun 2012
} 
Tabel 1

Customer Satisfaction Index Holcim

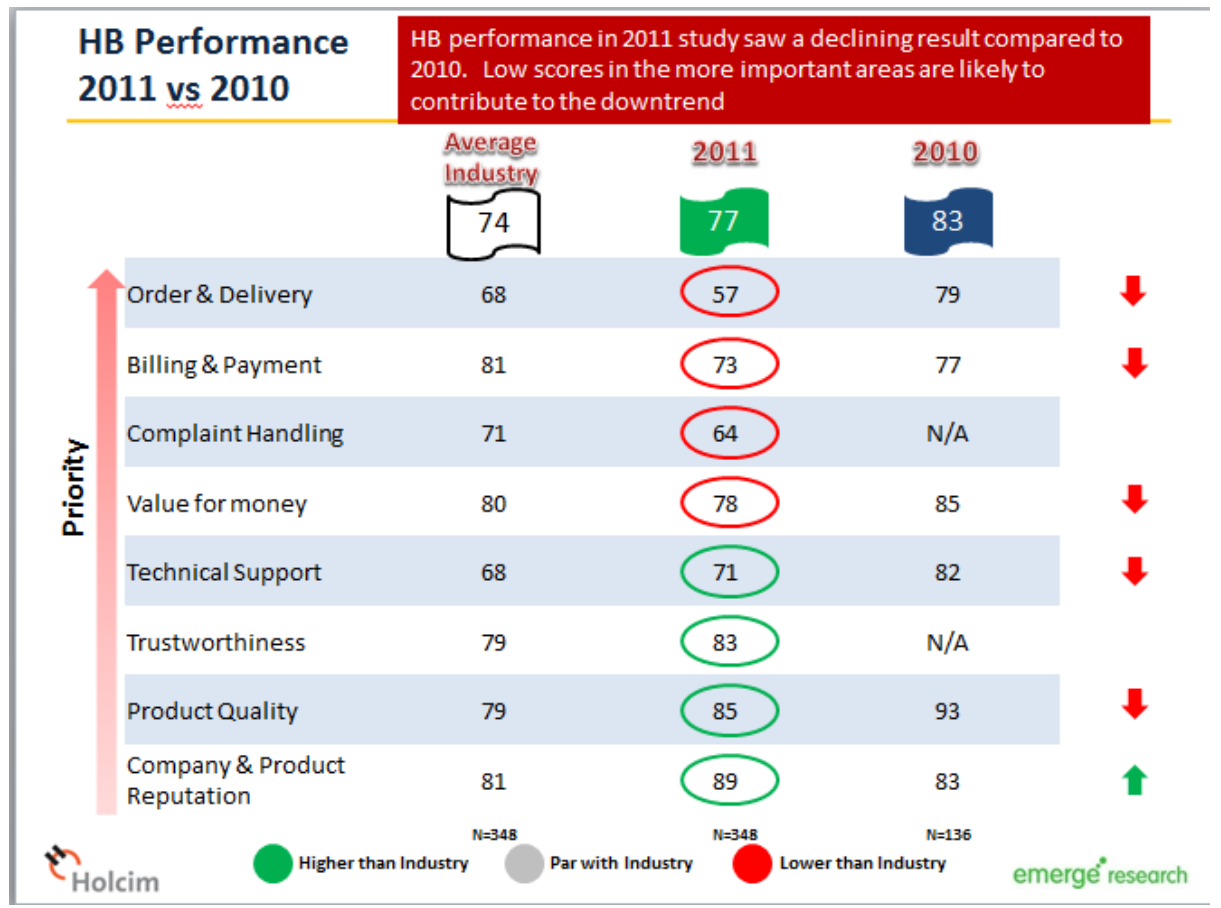

Sumber : Customer Satisfaction Index Holcim, Emerge Survey 2012

Survey tersebut dilakukan di Jakarta dan Surabaya, 287 pelanggan di Jakarta dan 62 Pelanggan di Surabaya. Pelanggan yang terdiri dari Multi Level (Bangunan Tinggi), Infrasruktur (Jalan, Jembatan, Powerplant), Industrial dan Commercial building dan rumah tinggal (retail).

Tabel 2

Jumlah Pelanggan yang di survey

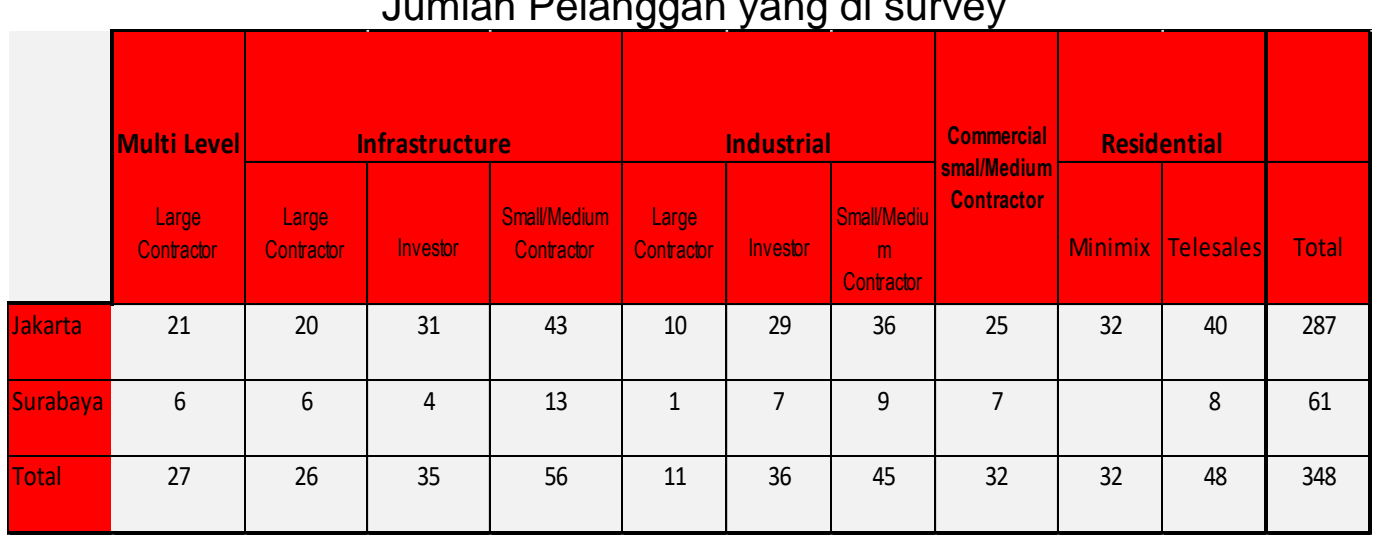

Sumber : Customer Satisfaction Index Holcim, Emerge Survey 2012 
Jumlah pelanggan yang disurvey table 2 diatas adalah pelanggan Holcim (lebih dari 5 kali menggunakan Holcim) dan diantara pelanggan Holcim tersebut pernah juga menggunakan beton siap pakai pesaing lainnya. Selain Holcim, tentunya para produsen semen seperti Indocement (Tigaroda), Semen Gresik, dan pemain baru melihat permintaan pasar Indonesia sebagai peluang besar.

Dalam artikel klasiknya "Customer Loyalty: Toward an integrated conceptual Framework" ${ }^{2}$ salah satu situasi dari empat situasi kemungkinan loyalitas berdasarkan dimensi sikap dan perilaku pembelian ulang adalah faktor Non-Sikap, yaitu dimana faktor subyektif dan faktor situasional lebih kuat pengaruhnya terhadap perilaku pembelian.

Faktor subyektif dan situasional dari sisi konsumen sendiri dalam memilih pemasok atau vendor, sebelum memutuskan menggunakan beton siap pakai, bisa didapat dari pengalaman mereka pada proyek-proyek sebelumnya maupun masukan dari pihak lainnya, seperti pemilik proyek, konsultan dan lain-lain. Holcim harus jeli melihat hal-hal yang di butuhkan dari konsumen, untuk menghindari berpalingnya pelanggan ke pesaing.

Adapun kriteria yang di pilih oleh pelanggan dari data survey pelanggan sebagai berikut :

Tabel 3

Kriteria seleksi Pemasok

\begin{tabular}{|l|l|c|}
\hline No. & \multicolumn{1}{|c|}{ Kriteria Seleksi Pemasok } & $\%$ \\
\hline 1. & Kualitas produk beton yang diberikan & 92 \\
\hline 2. & Kemampuan memenuhi spesifikasi yang di tentukan & $78 \%$ \\
\hline 3 & Harga sesuai dengan barang yang diterima & $76 \%$ \\
\hline 4. & Kemampuan memenuhi jumlah volume yang dibutuhkan & $75 \%$ \\
\hline 5. & Lokasi Batching Plant yang dekat dengan proyek & $74 \%$ \\
\hline
\end{tabular}

Sumber : Customer satisfaction study Holcim, Emerge Survey 2012

Dari kriteria diatas yang dipilih konsumen (dalam table 3), dapat diasumsikan bahwa faktor yang penting dalam pemilihan beton siap pakai adalah kualitas produk, termasuk di dalamnya pemenuhan spesifikasi, harga yang sesuai dengan barang yang diterima serta citra merek dari perusahaan.

\footnotetext{
${ }^{2}$ Dick \& Basu 1994, dalam Fandy Tjiptono, dan Gregorius Chandra, Pemasaran Strategik, Penerbit Andi - Yogyakarta, 2012 h :83,
} 
Dalam data survey yang dilakukan oleh majalah Marketing dan Frontier Consultant Group tahun 2012, seperti Tabel 4 berikut:

Tabel 4

TOP BRAND INDEX 2011 Fase 2-1

\begin{tabular}{|c|c|c|}
\hline Merk & TOP Brand Index & TOP brand \\
\hline Tiga Roda & $59.3 \%$ & TOP \\
\hline Gresik & $19.6 \%$ & TOP \\
\hline Holcim & $6.4 \%$ & \\
\hline Padang & $6.0 \%$ & \\
\hline Tonasa & $4.5 \%$ & \\
\hline
\end{tabular}

Sumber : http://www.topbrand-award.com/top-brand-survey/survey-result/top-brand-result-2011/

Tabel 5

TOP BRAND INDEX - Kategori Bahan Bangunan - Semen

\begin{tabular}{|c|c|c|}
\hline Merk & TOP Brand Index & TOP \\
\hline Tiga Roda & $55.1 \%$ & TOP \\
\hline Gresik & $20.8 \%$ & \\
\hline Holcim & $8.8 \%$ & \\
\hline Padang & $6.1 \%$ & \\
\hline Tonasa & $4.6 \%$ & \\
\hline Andalas & $3.2 \%$ & \\
\hline Sumber $:$ http://ww:topbrand-awardcom/top-brand-survey/survey-result/top-brand-result-2012/
\end{tabular}

Dari Tabel 4 dan tabel 5 , Top brand Index 2011 dan 2012, kategori bahan bangunan menyatakan bahwa Holcim termasuk 3 besar ( $\mathrm{TBI}=6.4 \%$ menjadi 8.8\%) setelah Tiga Roda dan Semen Gresik. Masih jauh di bandingkan dengan kedua pesaing besarnya ${ }^{3}$.

Masalah yang muncul pada penelitian ini adalah Menurunnya rasa kepuasan pelanggan Holcim, seperti tergambarkan dalam Customer Satisfaction Index 2010 dan 2011. Semakin bertambahnya pesaing Holcim, terutama para produsen semen yang ekspansi ke bisnis beton siap pakai. Harga yang tawarkan diatas dari harga pesaing, berpotensi proyek besar yang menjadi pelanggan Holcim, beralih ke pesaing. Citra merek pada kriteria bahan bangunan masih berada di bawah pesaing. Tingkat Loyalitas

\footnotetext{
${ }^{3}$ Sumber : http://www.topbrand-award.com/top-brand-survey/survey-result/top-brand-result-2011
} 
pelanggan masih dibawah dari pesaing, dan masih bisa di tingkatkan untuk memenangkan persaingan.

Dari permasalahan tersebut di atas, maka penelitian ini digunakan untuk menjawab permasalahan-permasahan yang muncul. Bagaimana gambaran kepuasan, loyalitas pelanggan beton siap pakai, kualitas produk, persepsi harga, dan citra merk di Jakarta? Apakah kualitas produk memiliki pengaruh terhadap kepuasan pelanggan beton siap pakai Holcim di Jakarta? Apakah persepsi harga memiliki pengaruh terhadap kepuasan pelanggan beton siap pakai Holcim di Jakarta? Apakah citra merek memiliki pengaruh terhadap kepuasan pelanggan beton siap pakai Holcim di Jakarta? Serta, apakah kepuasan pelanggan memiliki pengaruh terhadap loyalitas beton siap pakai Holcim di Jakarta?

\section{KAJIAN TEORI}

\section{Loyalitas Pelanggan}

Loyalitas dalam bahasa tradisional digunakan untuk menggambarkan kesetiaan dan pengabdian untuk negara atau perorangan dengan suatu tujuan. Dalam marketing, loyalitas didefinisikan sebagai suatu sikap yang ditunjukan oleh konsumen terhadap penyedia produk dan/atau jasa. Konsumen yang loyal adalah seorang konsumen yang selalu membeli kembali dari provider atau penyedia jasa yang sama. Loyalitas pelanggan tujuan akhir keberhasilan perusahaan menjalin hubungan relasi dengan pelanggannya adalah untuk membentuk loyalitas yang kuat. Indikator dari loyalitas pelanggan adalah 1) Say positive things, 2) Recommend friend, adalah merekomendasikan produk yang telah dikonsumsi kepada orang lain, 3) Continue purchasing, adalah pembelian yang dilakukan secara terus menerus terhadap produk yang telah dikonsumsi.

\section{Kepuasaan Pelanggan}

Kepuasan pelanggan adalah suatu keadaan dimana keinginan, harapan dan kebutuhan pelanggan dipenuhi. Kepuasan pelanggan sangat tergantung pada persepsi dan ekspektasi pelanggan. Terdapat empat faktor yaitu : pembelian ulang (re-purchase) menjelaskan keterikatan antara pelanggan dan produsen, sehingga bilamana langsung menggunakan. Kedua yaitu merekomendasikan kepada orang lain menjelaskan hubungan antara pelanggan dengan produsen, pelanggan merasa perlu untuk merekomendasikan kepada pihak lain, ketiga yaitu Komitmen untuk tidak beralih ke pesaing, rasa kedekatan secara emosional terkait dengan produk dan pelayanan 
berdasarkan pengalaman pelanggan selama penggunaannya. Kepuasan yang lebih inklusif adalah kepuasan yang di tentukan dengan persepsi kualitas pelayanan, kualitas produk, harga, faktor situasi dan faktor personal.

\section{Kualitas Produk,}

Produk adalah sesuatu (barang, jasa, orang, tempat, ide, informasi, dan/atau oraganisasi) yang bisa di tawarkan untuk memuaskan kebutuhan dan keinginan konsumen ${ }^{4}$. Kualitas produk, kualitas layanan, kepuasan pelanggan dan keuntungan perusahaan sangat erat kaitannya. Definisi Kualitas produk adalah gabungan dari ciri-ciri lebih (feature) dan karakteistik dari produk atau pelayanan dimana kemampuan tersebut untuk memuaskan sesuai degan kebutuhandan keingin pelanggan. Dimensi Kualitas Produk, apabila perusahaan ingin mempertahankan keunggulan kompetitifnya dalam pasarDimensi kualitas produk tersebut terdiri dari 1) Performance (kinerja), 2) Durability (daya tahan), 3) Conformance to specifications (kesesuaian dengan spesifikasi), 4) Features (fitur), 5) Reliabilty (reliabilitas), 6) Aesthetics (estetika), 7) Perceived quality (kesan kualitas) $)^{5}$.

\section{Persepsi Harga}

Harga bisa diartikan sebagai jumlah uang (satuan moneter) dan/atau aspek lain (non moneter) yang mengandng utilitas atau kegunaan tertentu yang di perlukan untuk mendapatkan sebuah produk. Harga adalah sejumlah uang yang dibebankan atas suatu produk atau jasa atau jumlah dari nilai yang ditukarkan konsumen atas manfaatmanfaat karena memiliki atau menggunakan produk atau jasa tersebut. Harga memiliki dua peranan utama dalam proses pengambilan keputusan para pembeli, yaitu Peranan lokasi dan Peranan informasi. Harga adalah satu-satunya unsur dalam berbagai unsur bauran pemasaran yang akan mendatangkan laba bagi peritel. Dari beberapa penelitian sebelum nya dimensi persepsi harga menurut pelanggan adalah kesesuaian harga dengan kualitas dan manfaat produk, daya saing harga (harga di antara pesaing), serta harga yang sesuai dengan harapan.

\footnotetext{
${ }^{4}$ Fandy Tjiptono, dan Gregorius Chandra, Pemasaran Strategik, Penerbit Andi - Yogyakarta, 2012.hal 313

${ }^{5}$ Philip Kottler, dan Keller Kevin 2012, Marketing Management, Pearson, Global Edition, 14e, 2012, hal. 313
} 


\section{Citra Merk}

Citra Merek merupakan bagian dari merek yang dapt dikenali namun tidak dapt diucapkan, seperti lambang, desain huruf atau warna khusus, atau persepsi pelanggan atas sebuah produk atau jasa yang di wakili oleh mereknya. Citra merek adalah persepsi masyarakat terhadap perusahaan atau produknya. Citra Merek dipengaruhi oleh banyak faktor yang di luar kontrol perusahaan. Citra Merek yang efektif akan berpengaruh terhadap tiga hal yaitu : Pertama, memantapkan karakter produk dan usulan nilai. Kedua, menyampaikan karakter itu dengan cara yang berbeda sehingga tidak dikacaukan dengan karakter pesaing. Ketiga, memberikan kekuatan emosional yang lebih dari sekadar citra mental. Supaya bisa berfungsi citra merek harus disampaikan melalui setiap sarana komunikasi yang tersedia dan kontak merek. Menurur Keller, Kevin Lane (2011: 538), Asosiasi yang timbul terhadap merek didorong oleh identitas merek yang ingin dibangun perusahaan, dan disebutkan asosiasi merek memiliki berbagai tipe yaitu Atribut (attributes), Manfaat (benefit), serta Sikap (attitudes) ${ }^{6}$.

\footnotetext{
${ }^{6}$ Philip Kottler, dan Keller Kevin. Ibid. hal 538
} 


\section{Penelitian Sebelumnya}

\section{Tabel 6}

Matrix Review Penelitian Relevan

\begin{tabular}{|c|c|c|c|c|c|c|c|}
\hline NO. & Nama Pengarang & Judul Penelitian & (X1) & (X2) & (X3) & $(\mathrm{Y})$ & (Z) \\
\hline 1. & Budi Hermawan, 2010 & $\begin{array}{l}\text { "PENGARUH KUALITAS PRODUK } \\
\text { TERHADAP KEPUASAN, REPUTASI } \\
\text { MEREK DAN LOYALITAS KONSUMEN } \\
\text { JAMU TOLAK ANGIN SIDOMUNCUL " }\end{array}$ & $\sqrt{ }$ & & $\sqrt{ }$ & $\sqrt{ }$ & $\sqrt{ }$ \\
\hline 2. & $\begin{array}{l}\text { Zhaohua Deng, Yaobin } \\
\text { Lu, Kwok Kee Wei, } \\
\text { Jinlong Zhang, } 2010\end{array}$ & $\begin{array}{l}\text { "UNDERSTANDING CUSTOMER } \\
\text { SATISFACTION AND LOYALTY : AN } \\
\text { EMPIRICAL STUDY OF MOBILE } \\
\text { INSTANT MESSAGES IN CHINA" }\end{array}$ & & & & $\sqrt{ }$ & $\sqrt{ }$ \\
\hline 3. & $\begin{array}{l}\text { Suhaji, Haris Munandar, } \\
2008\end{array}$ & $\begin{array}{c}\text { "PENGARUH PERSEPSI KUALITAS } \\
\text { PELAYANAN, KUALITAS PRODUK } \\
\text { DAN HARGA TERHADAP LOYALITAS } \\
\text { KEPUASAN PELANGGAN }\end{array}$ & $\sqrt{ }$ & $\sqrt{ }$ & & $\sqrt{ }$ & $\sqrt{ }$ \\
\hline 4. & $\begin{array}{l}\text { Jahanshahi, } \\
\text { Gashti, } \\
\text { Mirdamadi, } \\
\text { Nawaser, } \\
\text { Khaksar, } 2011\end{array}$ & $\begin{array}{l}\text { "STUDY THE EFFECTS OF } \\
\text { CUSTOMER SERVICE, PRODUCT } \\
\text { QUALITY, ON CUSTOMER } \\
\text { SATISFACTION AND LOYALTY" }\end{array}$ & $\sqrt{ }$ & & & $\sqrt{ }$ & $\sqrt{ }$ \\
\hline 5. & $\begin{array}{l}\text { Ruth Amryyanti, I Putu } \\
\text { Gde Sukaatmadja, Ketut } \\
\text { Nur Cahya, }\end{array}$ & $\begin{array}{l}\text { "PENGARUH KUALITAS LAYANAN, } \\
\text { PRODUK, DAN KEWAJARAN HARGA } \\
\text { TERHADAP KEPUASAN DAN } \\
\text { LOYALITAS PELANGGAN PADA LnC } \\
\text { SKIN CARE SINGARAJA" }\end{array}$ & $\sqrt{ }$ & $\sqrt{ }$ & & $\sqrt{ }$ & $\sqrt{ }$ \\
\hline 6 & $\begin{array}{l}\text { Tu, Yu-Te, Wang, Chin } \\
\text { Mei, Chang Hsiao- } \\
\text { Chien (2012) }\end{array}$ & $\begin{array}{l}\text { Corporate Brand Image and Customer } \\
\text { Satisfaction on Loyalty: An Empirical } \\
\text { Study of Starbucks Coffee in Taiwan }\end{array}$ & & & $\sqrt{ }$ & $\sqrt{ }$ & $\sqrt{ }$ \\
\hline
\end{tabular}

\section{Keterangan:}
X1 : Kualitas Produk
X2 : Persepsi Harga
X3 : Citra Merek
Y1 : Kepuasan Pelanggan
Y2 : Loyalitas Pelanggan

\section{METODE PENELITIAN}


Metode penelitian yang dilakukan dalam penelitian ini adalah deskriptif dan Kausal. Sedang metode kausal digunakan untuk membuktikan pengaruh produk kualitas, persepsi harga dan citra merek terhadap loyalitas pelanggan melalui kepuasan pelanggan secara parsial maupun secara simultan. Populasi dalam penelitian ini adalah seluruh pelanggan Holcim segmen Industrial dan Komersial yang pernah menggunakan beton siap pakai holcim selama 5 kali pengecoran dan juga menggunakan produk beton siap pakai dari pesaing di Jakarta sebanyak 100 pelanggan.

\section{Tabel 7}

Jumlah pelanggan per segementasi

\begin{tabular}{|l|l|c|}
\hline No & Segmentasi & Total Pelanggan \\
\hline 1 & Industrial - Big Contractor & 10 \\
\hline 2. & Industrial - Investor -Developer & 29 \\
\hline 3. & Industrial - Small/Medium Contraktor & 36 \\
\hline 4 & Commercial - Small/ Medium Contractor & 25 \\
\hline \multicolumn{2}{|c|}{ Total } & 100 \\
\hline
\end{tabular}

Sumber : data internal Holcim - diolah oleh peneliti

Untuk memperoleh data yang diperlukan dilakukan dengan cara memberikan kuesioner kepada responden. Kuesioner ini terdiri dari 5 bobot penilaian dengan skala likert yang menggambarkan persepsi responden mulai dari sangat tidak setuju hingga sangat setuju dengan skor 1 - 5 .

Perhitungan validitas menggunakan korelasi product moment dengan SPSS versi 20,0 dengan kriteria sebagai berikut: jika nilai $r$ hitung $>$ r tabel maka instrumen valid atau jika nilai $r$ hitung $<$ r tabel maka instrumen tidak valid. Hasil dari uji validitas, untuk varibel kualitas produk ada beberapa yang kurang dari 0.3 yaitu item $9,11,12$, dan 19 sementara untuk variable persepsi harga item 1,4 dan 6 ,variable citra merek item no 3, variable kepuasan pelanggan dan loyalitas pelanggan kesemua item valid. Dari beberapa item yang tidak valid tersebut, kesemuanya tidak merubah indicator atau pun dimensi yang sudah di tetapkan, dan item pernyataan yang tidak valid tidak digunakan dalam penetian.

Perhitungan reliabilitas menggunakan uji Cronbach's Alpha dengan SPSS versi 20,0 dengan kriteria sebagai berikut: jika nilai Cronbach' Alpha > 0,6 maka instrumen reliabel atau jika nilai Cronbach's Alpha < 0,6 maka instrumen tidak reliabel. Berdasarkan hasil uji reliabilitas yang telah dilakukan untuk semua variabel, didapatkan nilai Cronbach's Alpha untuk kualitas produk, persepsi harga, citra merek, kepuasan dan loyalitas pelanggan secara berurutan sebesar 0,$912 ; 0,797 ; 0,890 ; 0.915$ dan 0,923 ; berarti instrumen dinyatakan reliabel.

Dalam penelitian ini menggunakan tiga jenis asumsi klasik yaitu uji normalitas, uji heteroskedastisitas, dan uji multikolinieritas. Uji normalitas 
bertujuan untuk menguji apakah variabel terikat, variabel bebas, atau keduanya mempunyai distribusi normal atau tidak. Berdasarkan hasil uji Kolmogorov-Smirnov, nilai signifikansi secara berurutan untuk variabel kualitas produk, persepsi harga, citra merek, kepuasan dan loyalitas pelanggan adalah 0,$202 ; 0,137 ; 0,199 ; 0.163$ dan 0,052 . Kelima nilai signifikansi tersebut lebih besar dari 0,05 ; maka seluruh variabel tersebut berdistribusi normal.

Uji heteroskedatisitas dilakukan untuk mengetahui apakah dalam sebuah regresi terjadi ketidaksamaan varians dari residual suatu pengamatan ke pengamatan lain ${ }^{7}$. Uji heteroskedastisitas ini menggunakan Uji Park, yaitu meregresikan nilai residual $\left(\mathrm{Lnei}^{2}\right)$ dengan variabel terikat ( $\mathrm{LnX} 1$ dan $\left.\operatorname{LnX} 2\right)$. Hasil dari pengujian heteroskedastisitas menunjukan nilai sig $>0.5,-1.782$, 0.760 dan 1.017 artinya semua varibelitas $x 1, x 2$, dan $x 3$ tidak mengalami terjadi heterokesdastisitas.

Uji multikolinearitas berguna untuk mengetahui apakah pada model regresi yang diajukan telah ditemukan korelasi kuat antar variabel bebas ${ }^{8}$, hal ini diketahui dari besaran VIF (variance Inflaction factor), jika nilai VIF mendekati 1 berati tidak terjadi multikolineritas, variable kualitas produk 1.026, persepsi harga 1.019 dan citra merek 1.008 .

\section{HASIL PEMBAHASAN}

Karakteristik Responden berdasarkan lokasi proyek, terbesar ada di wilayah Tangerang 26\%, Bekasi-Karawang $18 \%$, Depok - Bogor $15 \%$, Jakarta Timur 12\%. Artinya diwilayah-wilayah tersebutlah bahwa pembangunan industrial dan bangunan komersial terbanyak berada. Di empat wilayah tersebut, Batching Plant Holcim Beton berada untuk melayani proyek-proyek tersebut.

Kualitas produk Holcim disusun oleh 22 item pertanyaan hasil refleksi jawaban responden dari segment Industrial dan Komersial. Ada beberapa hal yang masih dianggap kurang oleh responden pada penelitian ini, diantaranya sebagian besar responden mengangap mutu beton Holcim belum memenuhi syarat yang sesuai dengan permintaan. Pertama adalah bahan material yang yang digunakan bermutu kurang baik dan belum memenuhi persyaratan. Kedua, Holcim belum dapat memberikan desain komposisi campuran sesuai dengan permintaan/spesifikasi. Ketiga, sebagian besar responden memiliki anggapan Holcim belum dapat menyesuaikan komposisi campuran dengan kondisi pelaksanaan pengecoran (lamanya pengeoran), karena sering terjadi

\footnotetext{
${ }^{7}$ Husein Umar, Ibid hal.82

${ }^{8}$ Umar, Op.Clt. hal 80
} 
permasalahan di lapangan yang tidak diantisipasi oleh Holcim. Keempat, ternyata sebagian besar responden juga menganggap Holcim belum selalu memberikan hasil test Kualitas beton benda uji umur 28 hari.

Sebagian besar responden menganggap harga yang ditawarkan oleh Holcim tidak sesuai dengan ekspektasi dari pelanggan. Menurut responden, harga yang ditawarkan oleh Holcim belum sesuai dengan bahan material (Fly ash atau non Fly ash) yang digunakan. Responden kurang setuju harga beton dengan menggunakan material khusus selalu diinformasikan diawal. Harga beton yang ditawarkan belum sesuai dengan ekspektasi (harapan), serta harga beton yang ditawarkan dianggap tidak sesuai dengan penanganan bila ada masalah.

Sebagian besar responden beton siap pakai Holcim masih menjawab kurang setuju, dari beberapa indikator citra merek yang diteliti. Diantaranya tenaga trampil yang siap melayani pelanggan, selalu berinovasi dengan produk beton yang berkualitas, selalu memberikan Solusi bagi konsumen (dengan produk inovasinya), kemudahan dalam pesan beton, bisa bayar dengan kartu kredit, bisa bayar di lokasi Holcim terdekat, serta menggunakan material ramah lingkungan - recycle materials - kaitannya dengan "Green Concept". Metode pembayaran misalnya, proses pembayaran tidak boleh langsung pada tenaga penjual dianggap mempersulit atau terkesan tidak praktis karena harus melakukan pengurusan pembayaran, sebelum berlangsungnya pengecoran.

Hasil sebaran data di atas menunjukkan beberapa kekurangan yang masih dianggap kurang puasnya pelanggan. Diantaranya teknisi lapangan tidak siap bila di minta, responden juga menyatakan tidak selalu diberikan informasi yang tepat mengenai pengiriman oleh bagian pengiriman atau central dispatch, tidak kecukupan nya material di Batching Plant, Pengiriman yang tidak tepat waktu sesuai permintaan pelanggan, sulitnya mendapat jawaban dari SMS Holcim beton, sulitanya dihubungi Key account setiap waktu, serta informasi dari Customer Care mengenai jalannya pengecoran. Ketidakpuasan tersebut muncul ketika proses yang sedang dikerjakan tidak sesuai dengan harapan dari pelanggan dengan yang di berikan oleh Holcim.

Pada segment Industrial dan komersial, dimana produk beton siap pakai yang digunakan mayoritas (hampir semua) menggunakan mutu beton standar, dan para pelanggan cenderung menggunakan Holcim karena terpaksa, sehingga berdampak pada loyalitasnya. Responden menganggap kurang setuju ketika bila ada proyek baru menggunakan Holcim lagi, responden kurang puas dengan layanan Holcim, mereka tidak merekomendasikan Holcim kepada calon pembeli (kolega, keluarga,dll), tidak mau memberikan informasi bila ada proyek baru, tidak mau memberikan saran untuk pengembangan Holcim, serta tidak selalu menyertakan Holcim dalam tender. Akan tetapi kebanyakan responden setuju dengan beberapa hal. Mereka puas dengan kualitas Holcim, tidak lagi membandingkan harga 
dengan pesaing, bekerjasama untuk mendapatkan proyek baru, memberi informasi bila mengetahui sumber material baru untuk Holcim. Artinya, demi menjaga kualitas yang diinginkan, konsumen turut andil untuk mengarahkan dengan cara memilih material terbaik. Setelah konsumen membeli produk beton siap pakai Holcim, mereka tidak mau kualitas berubah atau tidak sesuai yang diinginkan. Sehingga Holcim juga berusaha sebaik mungkin sampai hasil yang memuaskan.

Dari hasil analisis kausalitas variabel Kualitas Produk (X1), Persepsi Harga (X2), serta Citra Merek (X3) terhadap Kepuasan Pelanggan (Y1). Analisis pengaruh ini menggunakan regresi linier berganda sebagai alat untuk mengukur besanya pengaruh. Hasil dari pengukuran ini adalah sebagai berikut.

Tabel 8

Koefisien Regresi, pengaruh Kualitas Produk, Persepsi Harga dan Citra Merek terhadap Kepuasan Pelanggan Coefficients $^{\mathrm{a}}$

\begin{tabular}{|c|c|c|c|c|c|c|}
\hline \multirow[t]{2}{*}{ Mod } & & \multicolumn{2}{|c|}{$\begin{array}{l}\text { Unstandardized } \\
\text { Coefficients }\end{array}$} & \multirow{2}{*}{$\begin{array}{c}\begin{array}{c}\text { Standardized } \\
\text { Coefficients }\end{array} \\
\text { Beta }\end{array}$} & \multirow[t]{2}{*}{$\mathrm{t}$} & \multirow[t]{2}{*}{ Sig. } \\
\hline & & B & Std. Error & & & \\
\hline \multirow{4}{*}{1} & (Constant) & 3.107 & 1.686 & & 1.843 & .068 \\
\hline & KPRO Kualitas Produk & .623 & .130 & .653 & 4.792 & .000 \\
\hline & HARGA Harga & .243 & .105 & .392 & 2.306 & .023 \\
\hline & CM Citra Merek & -.319 & 135 & -.371 & -2.357 & .020 \\
\hline
\end{tabular}

a. Dependent Variable: KPEL Kepuasan Pelanggan

Sumber : Hasil Olahan peneliti dengan SPSS $<2013$

Hasil dari tabel koefisien di atas diperoleh persamaan:

$$
Y=0,653 X_{1}+0,392 X_{2}-0,371 X_{3}
$$

Dari ketiga nilai koefisien tersebut, seluruh variabel signifikan. Variabel Kualitas Produk, Persepsi Harga dan Citra Merek mempunyai pengaruh signifikan karena memiliki nilai signifikansi di bawah 0,05 yaitu $0,000,0,023$ dan 0,020.

Pengaruh Kualitas Produk, Persepsi Harga, dan Citra Merek secara bersama-sama melalui Kepuasan Pelanggan memberikan dampak yang signifikan terhadap loyalitas. Ada indikasi bahwa terdapat indikator lain yang perlu diukur. Hasil dari analisis ini diperoleh output sebagai berikut. 
Koefisien Regresi, Pengaruh Kualitas Produk, Persepsi Harga, dan Citra Merek melalui Kepuasan Pelanggan Terhadap Loyalitas

Coefficientsa

\begin{tabular}{|c|c|c|c|c|c|c|}
\hline \multirow{2}{*}{\multicolumn{2}{|c|}{ Model }} & \multicolumn{2}{|c|}{ Unstandardized Coefficients } & Standardized & \multirow[t]{2}{*}{ t } & \multirow[t]{2}{*}{ Sig. } \\
\hline & & $B$ & Std. Error & Beta & & \\
\hline \multirow{4}{*}{1} & (Constant) & 9.962 & 1.459 & & 6.828 & .000 \\
\hline & X1_KPRO & .008 & .002 & .430 & 4.742 & .000 \\
\hline & X2_HG & .008 & .004 & .147 & 1.895 & .061 \\
\hline & $\mathrm{X} 3 \mathrm{CM}$ & .011 & .002 & .372 & 4.476 & .000 \\
\hline
\end{tabular}

a. Dependent Variable: Y2_LOYAL

Hasil dari tabel koefisien di atas diperoleh persamaan:

$Y=0,430 X_{1}+0,147 X_{2}+0,372 X_{3}$

Dari ketiga nilai koefisien tersebut, hanya $X_{2}$ yang tidak signifikan karena memiliki nilai signifikansi 0,061 atau lebih dari dari 0,05 . Sedangkan Kualitas Produk dan Citra Merek signifikan karena memiliki nilai signifikansi di bawah 0,05 yaitu 0,000 dan 0,000. Meskipun demikian, harga tetap signifikan pada taraf signifikansi $10 \%$, artinya pelanggan yang loyal mulai tidak memperhitungkan permasalahan harga.

Dari hasil análisis data menunjukkan bahwa Kepuasan Pelanggan produk beton siap pakai Holcim tidak dipengaruhi oleh Kualitas Produk dan Citra merek. Bila di telaah kembali semua responden dari segmen industrial dan komersial ini adalah B2B atau Bisnis to Bisnis, dimana para responden adalah mewakili dari responden perusahaan atau company, bukan pembeli retail atau end user. Sehingga bilamana pemilik proyek atau developer maupun kontraktor memutuskan untuk membeli beton Holcim, dengan harga yang sudah di tentukan dalam kontrak atau perjanjian untuk kurun waktu tertentu atau untuk proyek tertentu.

Seperti yang diutarakan sebelumnya bahwa beton siap pakai Holcim adalah bukan produk jadi, artinya produk tersebut dijual dan kemudian di olah oleh pembeli sehingga menjadi suatu elemen struktur dalam bangunan, yang artinya produk yang di beli memerlukan proses selanjutannya. Hal ini menunjukan bahwa pelanggan merasa puas terhadap apa yang dibeli atau puas setelah melampaui proses pekerjaan, sehingga pelanggan baru merasakan atau melihat kualitas produk yang dihasilkan, hingga akhirnya membentuk citra merek dari produk beton siap pakai Holcim.

Pengaruh yang terjadi pada hasil penelitian ini menunjukkan perbedaan yang mendasar dari penelitian-penelitian sebelumnya. Produk yang dijual Holcim bukanlah produk jadi, sehingga tidak dapat dilihat kualitasnya sebelum selesai dikerjakan. Padahal beton yang dikerjakan harus dibeli 
terlebih dahulu oleh konsumen. Sehingga terdapat hal-hal lain di luar variabel ini yang memiliki pengaruh terhadap kepuasan pelanggan.

1. Hasil penelitian ini menunjukkan arah yang berbeda antara Kepuasan Pelanggan dan Loyalitas Pelanggan. Secara langsung terhadap Kepuasan Pelanggan, variabel Persepsi Harga memiliki peran penting dalam menentukan Kepuasan Pelanggan. Akan tetapi setelah pelanggan mengalami kepuasan, Persepsi Harga bagi konsumen yang pernah menggunakan beton siap pakai Holcim tidak lagi menjadi bahan evaluasi terhadap Loyalitas. Namun Kualitas Produk dan Citra Merek menjadi lebih utama. Kepuasan Pelanggan terhadap suatu layanan disebabkan karena rasa percaya (trust), kualitas produk serta pelayanan, dan nilai-nilai yang terkandung di dalamnya (Zhaohua Deng dkk, 2009; Cia Hung-Hung, 2008).

2. Kualitas Produk tidak memiliki pengaruh terhadap Kepuasan Pelanggan. Kondisi pada saat ini harga yang ditawarkan Holcim cenderung paling tinggi bila dibandingkan dengan pesaingnya. Kualitas produk tidak memiliki pengaruh terhadap Kepuasan Pelanggan, tetapi memiliki pengaruh yang kuat terhadap Loyalitas. Seperti studi terhadap pelayanan pesan instant (SMS) di China, kualitas service berpengaruh signifikan terhadap Kepuasan Pelanggan (Zhaohua Deng dkk, 2009).

3. Harga memainkan peranan penting terhadap Kepuasan Pelanggan. Pelanggan yang hanya fokus melihat harga, dan akhirnya tidak langsung memilih Holcim karena merasa bahwa harga yang di tawarkan terkesan lebih tinggi atau paling tinggi di antara pesaingnya. Pada penelitian layanan jasa pesan instan di China harga berpengaruh secara langsung terhadap loyalitas (Zhaohua Deng dkk, 2009). Ini berbeda dengan produk beton siap pakai yang diproduksi oleh Holcim. Pelanggan yang membeli produk beton siap pakai perlu dilayani sesuai dengan permintaan serta jalannya kebutuhan konstruksi hingga terwujud menjadi suatu elemen struktur konstruksi, artinya pelanggan merasakan hasil dari produk tersebut setelah melalui proses dalam pekerjan konstruksi, hal ini. Mengakibatkan Harga tidak secara langsung mempengaruhi loyalitas, akan tetapi melalui Kepuasan Pelanggan terlebih dahulu.

4. Citra Merek memiliki peran yang kecil terhadap Kepuasan Pelanggan produk Holcim. Posisi Citra Merek dilihat setelah pelanggan merasakan Kepuasan terhadap layanan yang diberikan oleh Holcim baik sebelum proses konstruksi, saat proses kontruksi serta garansi (quality assurance), hal ini terbukti setelah Pelanggan Puas, maka Citra Merek menjadi berpengaruh signifikan terhadap Loyalitas Pelanggannya. Hal ini senada dengan penelitian Yu-Te Tu, Chin-Mei Wang, Hsiao-Chien Chang (2012), bahwa Citra Merek memiliki pengaruh yang signifikan 
terhadap Loyalitas Pelanggan. Pada satu waktu tertentu, Citra Merek mampu meningkatkan Loyalitas Pelanggan (Cia Hung-Hung, 2008).

5. Kualitas Produk, Persepsi Harga, serta Citra Merek memiliki pengaruh yang signifikan terhadap Loyalitas melalui kepuasan pelanggan. Kepuasan Pelanggan produk Holcim memiliki dampak pada pentingnya Kualitas Produk dan Citra Merek, sehingga konsumen atau pelanggan mengesampingkan masalah Harga. Hasil penelitian ini sesuai dengan penelitian sebelumnya yang menyatakan bahwa Kepuasan adalah faktor terpenting yang berpengaruh terhadap Loyalitas Pelanggan. Para ilmuwan menyatakan bahwa dalam hubungan jangka panjang pelanggan tidak hanya mengharapkan kualitas tinggi dari layanan utama tetapi juga manfaat tambahan dari melanjutkan suatu hubungan. Sejalan dengan penelitian yang dilakukan oleh Amryyanti, I Putu Gde Sukaatmadja, dan Ketut Nur Cahya (2010) mendapatkan hubungan kepuasan pelanggan memiliki pengaruh terhadap niat membeli. Kepuasan pelanggan berpengaruh positif terhadap loyalitas pelanggan.

\section{KESIMPULAN DAN SARAN}

\section{Kesimpulan}

Kualitas produk, Persepsi Harga, dan Citra Merek memiliki pengaruh yang signifikan terhadap Kepuasan Pelangan. Pengaruh secara bersamasama ketiga variable tersebut terhadap Kepuasan Pelanggan sebesar 0. 50 atau $50 \%$. Ketiga variabel ini secara bersama-sama memiliki pengaruh dalam menentukan Kepuasan Pelanggan.

Kualitas Produk saja tidak berpengaruh secara langsung terhadap Kepuasan Pelanggan beton siap pakai Holcim di Jakarta. Tebukti nilai signifikansi dari kualitas produk yang jauh di atas 0,05 , dengan besaran pengaruh $0,4 \%$. Terdapat indikator lain yang secara bersama-sama dengan Kualitas Produk memberi pengaruh terhadap Kepuasan Pelanggan.

Persepsi harga berpengaruh signifikan terhadap Kepuasan Pelanggan beton siap pakai Holcim. Pengaruh yang diberikan sebesar 0,073 atau sebesar 7,3 persen. Pada Segmen industrial dan komersial yang baru pertama kali menjadi konsumen Holcim mempertimbangkan Harga.

Citra merek tidak berpengaruh secara signifikan terhadap kepuasan pelanggan beton siap pakai Holcim di Jakarta. Pengaruh yang diberikan sebesar 0,001 atau $0,1 \%$, sedangkan sisanya dipengaruhi oleh variabel lain. Citra merek dipertimbangkan oleh konsumen setelah pelanggan merasakan pelayanan yang diberikan oleh Holcim. Ini terbukti setelah pelanggan puas, maka citra merek berpengaruh signifikan terhadap loyalitasnya.

Kepuasan memiliki pengaruh yang signifikan terhadap loyalitas pelanggan. Secara bersama-sama Kualitas Produk, Persepsi Harga, serta 
Citra Merek memiliki pengaruh yang signifikan terhadap loyalitas melalui kepuasan pelanggan. Hasil penelitian ini menunjukkan semakin membuat pelanggan merasa puas, maka akan berdampak pada loyalitasnya. Akan tetapi, perlakuan antara pelanggan yang belum puas dengan pelanggan yang sudah puas harus memiliki perbedaan. Kepuasan pelanggan di awal ditentukan oleh harga, sedangkan pelanggan yang sudah puas tidak mempertimbangkan Harga, melainkan kualitas produk dan citra merek produk Holcim. Artinya untuk membuat pelanggan menjadi loyal, haruslah membuat pelanggan puas terlebih dahulu.

\section{Implikasi}

Kepuasan Pelanggan tidak hanya dapat ditingkatkan hanya meningkatkan kualitas produk dan citrak merek saja, secara parsial. Dimata konsumen semakin rendah atau murah maka Kepuasan Pelanggan semakin meningkat, Konsumen atau pelanggan mudah memilih pemasok mana yang bisa melayani dengan harga murah, dengan mutu kualitas yang standar. Produk yang ditawarkan oleh Holcim termasuk harga premium atau paling mahal dibandingkan pesaing, namun untuk perusahan besar yang bekerja sama ada keyakinan bahwa kesanggupan pengiriman termasuk di dalamnya selain faktor harga yang murah saja.

Pelanggan beton siap pakai merasakan loyal, bilamana sudah merasa puas dengan kualitas produk yang di berikan oleh Holcim dan sesuai dengan citra ataupun reputasi dari perusahaan tersebut. Pelanggan beton siap pakai harus merasakan pernah menggunakan produk tersebut, merasa puas setelah menggunakan produk tersebut sehingga secara otomatis rasa loyal terhadap Holcim. Konsumen setuju untuk menyampaikan kepada rekan atau bersedia menggunakan beton siap pakai Holcim pada proyek berikutnya.

Pelanggan yang merasakan puas menggunakan beton siap pakai Holcim atas kualitas produk maupun pelayanannya, menjadikan harga tidak penting dan tetap bersedia menggunakan atau membeli produk beton siap pakai Holcim walaupun harga yang di tawarkan lebih mahal di bandingkan dengan harga yang di tawarkan oleh pesaingnya.

\section{Saran}


Holcim diharapkan memililiki dua strategi pemasaran. Pertama, bagi konsumen baru pengguna Holcim harus mampu melayani konsumen dalam hal central dispatch atau hot line service Holcim yang mudah dihubungi. Kedua, bagi konsumen yang sudah pernah menggunakan produk Holcim pelayanan terfokus pada kualitas produk dan citra merk.

Penelitian selanjutnya dapat mengembangkan penelitian tentang kepuasaan dan loyalitas pelanggan beton siap pakai Holcim berdasarkan segmen yang berbeda, untuk memberikan gambar yang lebih luas tentang kepuasaan dan loyalitas pelanggan di area berbeda atau segmen yang berbeda.

\section{DAFTAR PUSTAKA}

Aryani, Dwi dan Rosinta, Febrina, 2010, Pengaruh Kualitas Layanan terhadap Kepuasan Pelanggan dalam Membentuk Loyalitas Pelanggan, Jurnal IImu Administrasi dan Bisnis, Volume 17, No,2 hal 114 - 126 ISSN 0854 - 844 edisi Mei - Agust 2010.

Asghar Afshar Jahanshahi, Mohammad Ali Hajizadeh Gashti, Seyed Abbas Mirdamadi, Khaled Nawaser, Seyed Mohammad Sadeq Khaksar, 2011, "STUDY THE EFFECTS OF CUSTOMER SERVICE, PRODUCT QUALITY, ON CUSTOMER SATISFACTION AND LOYALTY" International Journal of Humanities and Social Science Vol. 1 No. 7; [Special Issue -June 2011]

Deliyanti Oentoro, Manajemen Pemasaran Modern, 2010, Laks Ban PRESSindo, Yogyakarta.

Donnelly, Martina ; Lynch Patrick, Holden T Mary, 2010, Building Loyalty : Creating Value Through Customer Experiences, competitive paper - un published Waterford Institute

Dua Lembang, Rosvita Analisis Pengaruh Kualitas Produk, Harga,

Promosi, dan Cuaca terhadap, Keputusan Pembelian Teh Siap Minum Dalam Kemasan Merek TEH BOTOL SOSRO, (Studi Kasus Pada Mahasiswa Fakultas Ekonomi Pasca sarjana, Universitas Diponegoro), Hooley Graham, Percy F Nigel, Nicoulaud Briggitte, 2008, Marketing Strategy and Competitive Positioning, fourth edition, Prentice Hall. Istijanto, Riset Sumber Daya Manusia; Cara Praktis Mendeteksi Dimensidimensi Kerja karyawan (Jakarta: PT. Gramdeia Pustaka Utama, 2008). Japrianto, Edwin, 2007, Analisa Kualitas Layanan sebagai Pengukur Loyalitas Pelanggan Hotel Majapahit Surabaya dengan Pemasaran Relasional sebagai Variabel Interveving, Jurnal Jurusan Manajemen Perhotelan, Fakultas Ekonomi - Universitas Kristen Petra Surabaya http://www.petra.ac.id/ puslit /journals/dir.php?Department 
Keegan, J .Warren and Green, C Mark , 2011, Global Marketing, Global Edition, sixth edition, Pearson, ISBN 13:978-0-13-704268-5

Kottler, Philip dan Keller Kevin 2012, Marketing Management, Pearson, Global Edition, 14e.

Keller, Kevin Lane, 2011, Strategic Brand Management, Building Measuring and Managing Brand Equity, New Jersey : Prentice Hall

Kuusik Andreas, A ffecting Customer Loyalty : Do Different Factors have Various influences in different Loyalty level, ISSN 1406 - 5967 ISBN 978-9949-11-735-2, Tartu University, www.tyk.ee

Lovelock Christopher, and Wirtz Jochen, 2011, Service Marketing, Pearson 2011

Masyhudzulhak, Memahami Penulisan Ilmiah dan Metode Penelitian, Lembaga Pengkajian dan pengembangan Sumber Daya, LP2S - 2012.

Nurmiyani, 2009, Analisis Pengaruh Citra Merek, Kualitas Produk dan Promosi Penjualan terhadap Citra Perusahaan (Studi pada CV. Aneka Ilmu Cabang Cirebon). Program Studi Magister Manajemen Universitas Diponegoro. Thesis tidak dipublikasikan.

Priyatno, Duwi, 2008. Mandiri Belajar SPSS Untuk Analisis Data dan Uji Statistik. Yogyakarta: Mediakom.

Rizan, Mochammad 2010, ANALYSIS OF SERVICE QUALITY AND CUSTOMER SATISFACTION, AND ITS INFLUENCE ON CUSTOMER LOYALTY. (Passengers Survey of Domestic Full Service Airlines Company "Garuda Indonesia" in Indonesia), Oxford Business \& Economic Conference Program ISBN 978- 0-9742114-1-9, Management Department of Economics Faculty, State University of Jakarta, Indonesia.

Rahma, Eva Sheilla 2007, Analisis Pengaruh Kualitas Layanan dan Citra Merek terhadap Minat Beli dan Dampaknya pada Keputusan Pembelian (Studi Pada Pengguna Telepon Seluler Merek Sony Ericson di Kota Semarang), Program Magister Manajemen Universitas Diponegoro, Thesis tidak dipublikasikan.

SA, Surachman (2008), Dasar-dasar Manajemen Merek, Alat Pemasaran untuk Memenangkan Persaingan, ISBN 978-979-3323-22-0, Bayumedia Publishing.

Sekaran, Uma, 2006. Metodologi Penelitian Untuk Bisnis, edisi keempat. Jakarta: Salemba Empat. 
Sekaran Uma dan Roger Bougie. 2011. Research Methods for Business: A Skill Building Approach. Fifth Edition. John Willey\& Sons Ltd.

Sugiyono. 2012. Metode Penelitian Bisnis. Bandung: Alfabeta.

Suhaji, Sunandar Haris (2010), Pengaruh Persepsi Kualitas Pelayanan, Kualitas Produk dan Harga terhadap Loyalitas Pelanggan Flexi di Kota Semarang dengan Intervening Kepuasan Pelanggan, Jurnal Marketing Ekonomi ASET vol 12.

Surjaatmadja Surachman, 2010 , Pemasaran jasa Alat untuk mencapai kinerja Unggul, Fakultas Ekonomi YARSI, 2010

Syverson, Chad ( 2005), Market Readymixed Concrete, National Bureau of Economic Research, Cambridge, Massachusetts.

Tjiptono, Fandy dan Chandra Gregorius ( 2012), Pemasaran Strategik, Penerbit Andi - Yogyakarta,

Warta Semen Beton Indonesia Volume 10, No.1 tahun 2012, majalah Asosiasi Semen Indonesia - Institute Semen dan Beton Indonesia, Jakarta.

Warta Ekonomi Flash online edisi Rabu 13 Maret 2013.

Virvilaite Regina, Saladiene Violeta, Skindaras Dalius, The Relationship between Price and Loyalty in Services Industry, Kaunas University of Technology Laisves av, 55, LT-44309 Kaunas, ISSN $1392-2785$ Inzinerine Ekonomika-Engineering Economics(3). 2009 COMMERCE OF ENGINEERING DECISIONS

Wheelen, L Thomas dan Hunger, J David (2012), Strategic Management and Business Policy - Toward Global Sustainability, Pearson Thirteenth Edition

Yu-Te, Chu-Mei Wang, Hsiao- Chien Chang Chungyu, Corporate Brand Image and Customer Satisfaction on Loyalty: An Empirical Study of Starbuck Cofee in Taiwan, Institute of Technology Taiwan Journal of Social and Development Sciences Vol. 3, No. 1, pp. 24-32, Jan 2012 (ISSN 2221-1152)

Zeithaml, Valarie A and Bitner, Mary Jo, 2011 Service Marketing, Mc Graw Hill, Inc, Int'l Edition New York

Zhaohua Deng, Yaobin Lu, Kwok Kee Wei, Jinlong Zhang, 2010, Understanding Customer Satisfaction and Loyalty, an Empirical study of Mobile Instant Messages in China, International Journal of Information Management 30(2010) 289-300. 